\title{
THE PSYCHOLOGY OF DENOMINATIONALISM.
}

By P. T. Hale, D.D., Louisville, Ky.

A knowledge of psychology, especially as practical and thorough as it has now been made, is of immense value to the thoroughly equipped modern preacher. Eminently is this the case with the psychology of religion. President Faunce of Brown University brings out in a most interesting way the advantages of psychological studies to the preacher in his Yale lectures. The study of such scientific works as William James" "The Varieties of Religious Experience", Professor Starbuck's "Psychology of Religious Experience', Professor E. S. Ames' "The Psychology of Religious Experience", and other modern works on this comparatively new science, not only broadens the view and adds to the culture of the preacher, but may be made of great practical helpfulness in a useful and up-to-date ministry. Perhaps the best definition of conversion, from the human and psychological side, is that given by the famous Harvard professor, William James. "Conversion, experience of grace, obtaining religion", says this able psychologist, "are so many terms which express the act, instantaneous or gradual, by which a self hitherto divided, and consciously wrong, inferior and unhappy, becomes united and consciously right, superior and happy, in consequence of the realization of religious verities."

It is interesting to study the origin and character of the various religious denominations from the human and psychological standpoint. "A psychological interpretation of the different Christian sects", says Professor E. S. Ames, "requires that they be regarded as social organisms whose life history is much fuller and richer than can be measured by their intellectual doctrines." They are products of great social movements. Religion to be practical can never be dissociated from social conscious- 
ness. Each denomination represents a type of personality and a social stratification through economic forces and the able personal leadership which has largely guided it. It is built up by like-minded people largely of the same social stratum. Protestantism originated in the disintegration of medieval, social, and ecclesiastical unity, and the assertion of a greater personal individualism. It was a revolt against state and church absolutism. Martin Luther incarnated this spirit, combined with the most profound moral earnestness. His people, whose champion and spokesman he became, groaned under the burden of papal taxation to make possible the magnificence of St. Peter's at Rome, and to defray the expenses of a dissolute and luxurious papacy. His visit to Rome deepened the sense of the immorality of the sale of indulgences to the people, and aggravated his sense of the effrontery of the pope's representatives imposing upon the credulity of the ignorant and superstitious. As he went through the humiliating act of climbing up the "Scala santa", which the visitor to Rome witnesses even to this day, there came to him with intense power the Scriptural declaration, "The just shall live by faith".

It may be truly said that Calvinism expresses, even to a greater extent, the mental traits and environment of its eminent founder. Calvin was an intellectual colossus, a lawyer, and a student. He wrote his great institutes in terms of law and of final and indisputable authority. To him the Bible was a law book with a complete code. The elect, in his view, were the spiritual aristocracy, part of a chosen and superior order. Thus his theological system relieves the elect of the dominating authority of pope and state, and are thus directly related to a Supreme Authority, the Infinite and Eternal God, between whom no human authority, civil or religious, had any right to intervene. To this extent Calvinism is democratic. But there was another side and appeal to it. His system left little place for individual volition and initiative. The 
individual did not stand alone, but was one of a vast and chosen host. This characteristic appealed, and still appeals, to certain classes. His intellectualism and learning appealed to the intelligent, and to men in whom there was a strong sense of solidarity, such as the people of Scotland and the English artisans, with the consciousness of their guilds and class interests. With this feeling of being elect members of a heavenly Kingdom, Calvinism went on to develop a fine scorn and impatience of all authority of a tyrannical nature, whether governmental or papal. Thus the Presbyterians in Virginia stood with the Baptists in a-vigorous protest against Episcopacy and state domination of religion in our great struggle for religious liberty in that state. The Puritans especially displayed this contempt for the authority of king and pope which drove them at last to the bleak New England coast. They rose above sensual indulgence and even bodily comfort.

Episcopalianism, originating in the peculiar situation of Henry VIII, was well adapted to the court circle, and to an aristocratic and esthetic order and type of mind. It was agreeable to a superior and leisure class, possessing wealth and station. They found satisfaction in a religion which exalted the proprieties of long usage, and was characterized by stately ceremonial, and which involved no strenuous self-denial in conflict with the tastes and enjoyment of high class society. Its appeal was, and is to the leisurely and cultured, who desire to observe the form of religion without serious interference with their pleasures and esthetic sensibilities, and which admits them into a high social circle.

Methodism was a reaction against both the coldness, neglect, and formalism of the established church, and the hyperpredestinarianism of Calvinism, and which emphasized the freedom of the individual and the experience of each soul of spiritual religion. Puritanism had suppressed, under Cromwell, all popular amusements, and 
had made Sunday a difficult day. Methodism offered means of emotional excitement and stirring demonstration, and the great religious revivals furnished recreation as well as religious excitement. Methodism laid great stress upon outward exhibition of the deepest emotions of the human soul. While John Wesley himself was not a man given to the outward expression of feeling, he was one of the most intense and dominant personalities of his age; and while he never wept through a sermon, as did Whitfield, and even the intellectual Jonathan Edwards, he tapped the reservoir of feeling whose streams have been flowing on to this day. Methodism presented the doctrine of regeneration and religious experience as something within the possibility of all persons and in comparison with which all other attainments, possessions, and achievements, such as learning, creeds, wealth, and social position, were as the dust of the balance. He established a new social fraternity whose mem. bers, possessing this experience, felt themselves the happy members of a mystic company, journeying on to the Heavenly City.

Christian Science represents the latest and in some ways most significant of contemporaneous religious cults. Mrs. Mary Baker Eddy believed that she was healed by mental science. Her doctrine is a strange compound of the erroneous interpretation of Bible texts and of Oriental pseudo-philosophical optimism, which appeals to uncritical people, worried by nervous diseases over which the mind possesses a really healing influence. It uses the Bible in a wholly unscientific and allegorical manner of interpretation, and appeals to the natural superstition and mysticism of a certain type of mind. It is a popular revolt against overmuch medicine. Prestige is given it by its exaltation of the feminine factor of the "MotherGod", and in having attractive women readers in the conduct of public services, thus introducing the sex influence, and it has provided elaborate places of worship, beauti- 
ful, and brilliantly lighted, and keeps up the appearance of prosperity and culture, so attractive to many people in this commercial age. It appeals to people who primarily seek their own comfort, and are able to pay for it, and it participates, to only a meager extent in charities and missions, and seeks to prey upon other denominations and to gain its adherents from them, rather than by an effort to reach the neglected religiously. There is the desire for health and personal comfort in a tense and nervous age, and its most potent appeal is to this class.

In religion, as in the state, no single doctrine or virtue can meet the deep and manifold needs of our entire and many-sided social life. Much energy has been wasted in the exclusive and intolerant advocacy of special doctrines, which are made supreme, to the neglect of other important truths and aims. Loyalty to party is essential to the preservation of government, but should never be placed above patriotism-the loyalty to the entire nation; and no sectarian loyalty should ever be placed above the common welfare, and the wide and permanent progress of the Kingdom of God.

Years ago I heard Henry Ward Beecher say, in a notable popular lecture, that different denominations were characterized by different striking idiosyncrasies and peculiarities. If a man was governed by his emotions, he would be attracted to the Methodist Church. If he was a worshiper of the intellect, he would be a Presbyterian. If he wanted somebody else to take the responsibility for him, he would be a Roman Catholic. If he loved the formal, refined, and esthetic, the Episcopal Church held out supreme attraction to him. If he was a literalist, he would be a Baptist. The great orator might have added, if his supreme thought was of the body and its own comfort, he would be attracted by Christian Science.

Are there not lessons for us, as Baptists, in such a study of denominationalism? While remaining absolutely loyal to the teaching of our Lord and Master, ought 
we not, through a generous and adequate equipment and maintenance of our denominational schools and through a thoroughly trained as well as devout ministry, be unsurpassed by the Presbyterians? And by our culture and ability to appeal to all that is beautiful and elevating of an esthetic nature equal the Episcopalians? And by our heartfelt appeal to the profoundest emotions of the heart, surpass the Methodists? And by the erection and sustenance of our hospitals, surpass Christian Science in its emphasis on health? Thus not neglecting anything that is advantageous to the whole man, but by a burning evangelistic and missionary spirit let us be more zealous and devoted in carrying a complete gospel which shall appeal to every human faculty to all nations and tongues and peoples, until the knowledge of the Lord shall cover the earth as the waters cover the sea. 